\title{
Creation of Potent Vitamin D Receptor Agonists and Antagonists with $2 \alpha-(\omega$-Hydroxyalkylation) Concept to the seco-Steroid Skeleton
}

\author{
Atsushi Kittaka*
}

\begin{abstract}
D$ skeleton with a $2 \alpha-(\omega$-hydroxyalkyl) or $2 \alpha-(\omega$-hydroxyalkoxy) group improves vitamin $\mathrm{D}$ receptor (VDR) binding affinity, lengthens the half-life in target cells because of increased resistance to CYP24A1 metabolism, and enhances biological activity. The introduced terminal hydroxy group forms an additional hydrogen bond to Arg274, which is the most important amino acid residue for recognizing the ligand hormone $1 \alpha, 25$-dihydroxyvitamin $\mathrm{D}_{3}$ of human VDR. According to our $2 \alpha$-functionalization concept, we synthesized several hundred vitamin $\mathrm{D}$ analogs, and some had selective potent biological activity, such as bone formation (by AH-1) or anticancer activity (by MART-10), without the side-effects of vitamin D such as hypercalcemia. A potent hVDR antagonist NS-74c and stable 14-epi-tachysterol derivatives are also described in this short review.
\end{abstract}

Keywords: Agonist · Antagonist · Tachysterol $\cdot$ Vitamin D $\cdot$ Vitamin D receptor

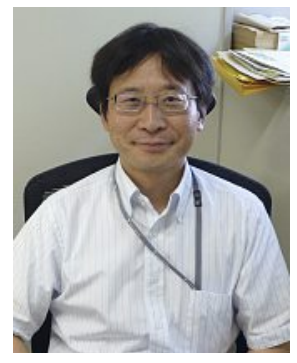

\section{Atsushi Kittaka}

was born in 1959 in

Shizuoka, Japan. He obtained a Bachelor of Pharmaceutical Sciences from the University of Tokyo in 1982, and he received his $\mathrm{PhD}$ from the University of Tokyo under the direction of Prof. Masaji Ohno in 1987. He did his postdoctoral work with Prof. Albert Eschenmoser for two years at ETH Zürich. He joined the School of Pharmaceutical Sciences at Showa University in Tokyo as an Assistant Professor in 1989, and he was promoted to Lecturer in 1994. In 1999, he moved to the Faculty of Pharmaceutical Sciences at Teikyo University as an Associate Professor, and then was appointed to Professor in 2003. His current research interests include the design and synthesis of highly active ligands of nuclear receptors (and others unknown) and protein-protein interaction triggered by ligand binding to receptors. He is a recipient of the Brown University Vitamin D Research Award 2007 and Miyata Memorial Award 2008.
${ }^{\star}$ Correspondence: Prof. A. Kittaka Faculty of Pharmaceutical Sciences Teikyo University

2-11-1 Kaga, Itabashi, Tokyo 173-8605, Japan

E-mail: akittaka@pharm.teikyo-u.ac.jp

\section{Introduction}

1 $\alpha, 25$-Dihydroxyvitamin $\mathrm{D}_{3}$ or $1 \alpha, 25(\mathrm{OH})_{2} \mathrm{D}_{3}$, the most physiologically active hormonal form of vitamin $\mathrm{D}_{3}$ in humans, regulates cellular proliferation and differentiation, apoptosis, and immune responses, in addition to its major classical roles in calcium and phosphorus homeostasis and bone mineralization. ${ }^{1]}$ The cellular and physiological actions of $1 \alpha, 25(\mathrm{OH})_{2} \mathrm{D}_{3}$ are mediated primarily through the vitamin D receptor (VDR), which belongs to the nuclear receptor superfamily and acts as a ligand-dependent transcription factor.[2] The biology of VDR- $\left[1 \alpha, 25(\mathrm{OH})_{2} \mathrm{D}_{3}\right]$ signaling involves stimulation of intestinal calcium and phosphate absorption to prevent rickets, enhancement of bone remodeling, differentiation of skin cells, and potential anticancer actions through the control of epithelial cell growth and differentiation. However, the therapeutic use of $1 \alpha, 25(\mathrm{OH})_{2} \mathrm{D}_{3}$ is limited because $1 \alpha, 25(\mathrm{OH})_{2} \mathrm{D}_{3}$ causes serious side effects, such as hypercalcemia and hyperphosphatemia, at superphysiological levels. Therefore, numerous analogs of $1 \alpha, 25(\mathrm{OH})_{2} \mathrm{D}_{3}$ have been developed, which are more efficacious, safer, and more selective than $1 \alpha, 25(\mathrm{OH})_{2} \mathrm{D}_{3}$. Chemical modifications on the seco-steroidal skeleton of $1 \alpha, 25(\mathrm{OH})_{2} \mathrm{D}_{3}$, such as eldecalcitol, maxacalcitol, tacalcitol, calcipotriol, paricalcitol, and falecalcitriol, are clinically used to treat osteoporosis, bone diseases, secondary hyperparathyroidism, and psoriasis. ${ }^{[1]}$
We synthesized several hundred vitamin $D$ analogs with different $2 \alpha$-functional groups, which form additional hydrogen bonds between the ligand A-ring and $\operatorname{Arg} 274$ at the VDR ligand binding domain (LBD), and some had strong agonist or antagonistic activity for human VDR (hVDR).

\section{2. $01 \mathrm{C3}$ and 02C3: Development of Superagonists of hVDR that Form Additional Hydrogen Bonds with hVDR}

When $1 \alpha, 25(\mathrm{OH})_{2} \mathrm{D}_{3}$ binds to hVDR, six hydrogen bonds are formed between the three hydroxy groups of $1 \alpha, 25(\mathrm{OH})_{2} \mathrm{D}_{3}$ and the six amino acid residues of the LBD of hVDR. One of the most important hydrogen bonds connects the $1 \alpha-\mathrm{OH}$ group of $1 \alpha, 25(\mathrm{OH})_{2} \mathrm{D}_{3}$ to the $\operatorname{Arg} 274$ residue of the receptor. ${ }^{[3]}$ The binding affinity of $1 \alpha, 25(\mathrm{OH})_{2} \mathrm{D}_{3}$ to hVDR is 500 1000 times stronger than that of 25-hydroxyvitamin $\mathrm{D}_{3}\left[25(\mathrm{OH}) \mathrm{D}_{3}\right]$. The LBD of hVDR contains water molecules from the A-ring anchoring moiety to the surface of the protein to stabilize the VDR$\left[1 \alpha, 25(\mathrm{OH})_{2} \mathrm{D}_{3}\right]$ complex by forming a hydrogen bond network with these water molecules. This water molecule network is called a water channel. ${ }^{[4]}$ We synthesized $2 \alpha$-(3-hydroxypropyl)-1 $\alpha, 25(\mathrm{OH})_{2} \mathrm{D}_{3}$ $(\mathrm{O} 1 \mathrm{C} 3)^{[5]}$ and $2 \alpha$-(3-hydroxypropoxy)$1 \alpha, 25(\mathrm{OH})_{2} \mathrm{D}_{3} \quad(\mathrm{O} 2 \mathrm{C} 3),{ }^{[6]}$ which have 3-times and 1.8-times higher VDR binding affinity, respectively, than $1 \alpha, 25(\mathrm{OH})_{2} \mathrm{D}_{3}$ 
(Fig. 1).[7] X-ray co-crystallographic analyses of both VDR-O1C3 and VDR-O2C3 complexes clearly revealed that the terminal hydroxy group of both synthetic ligands forms a hydrogen bond with the guanidino group of the Arg274 residue and replaces one of the water molecules in a hydrogen bond with the guanidino group of the LBD of hVDR to stabilize the complex. ${ }^{[4]}$ Therefore, $\mathrm{O} 1 \mathrm{C} 3$ and $\mathrm{O} 2 \mathrm{C} 3$ form pincertype complexes using two $\mathrm{OH}$-groups at the $1 \alpha$-position and the $\omega$-position of the $2 \alpha$-side chain with hVDR through the guanidino group of Arg274 (Fig. 2). O1C3 and O2C3 have greater biological activities in vitro and in vivo, including transactivation of target genes, induction of HL-60 cell differentiation, and elevation of rat serum calcium concentration, than those of the natural hormone $1 \alpha, 25(\mathrm{OH})_{2} \mathrm{D}_{3} \cdot{ }^{[5,6,8]}$

The $2 \alpha$-substituted active vitamin $\mathrm{D}_{3}$ analogs, including $\mathrm{O} 1 \mathrm{C} 3$ and $\mathrm{O} 2 \mathrm{C} 3$, are resistant to metabolism by CYP24A1, which is an inactivating enzyme of $1 \alpha, 25(\mathrm{OH})_{2} \mathrm{D}_{3}$ and $25(\mathrm{OH}) \mathrm{D}_{3}$, and the $2 \alpha$-modified ligand has a long half-life in target cells. ${ }^{[9]}$ The resistance of vitamin D analogs to CYP24A1-dependent metabolism may prolong their biological effects.

\section{AH-1: A Potent Therapeutic for Bone Formation in vivo without Calcemic Activity}

Based on the above results, we tried to use nitrogen atoms of an azole ring, instead of the hydroxy group on the introduced $2 \alpha$-side chain to create additional pincertype hydrogen bonds with the Arg274 residue. We studied the effects of azole rings, such as tetrazole, triazole, and imidazole, at the $2 \alpha$-position of $1 \alpha, 25(\mathrm{OH})_{2} \mathrm{D}_{3}$ on binding to hVDR and on biological activities in vitro and in vivo.

$2 \alpha-[2-($ Tetrazol-2 - y l) e thy 1$]$ $1 \alpha, 25(\mathrm{OH})_{2} \mathrm{D}_{3}$ (1a: AH-1) and the related compounds $\mathbf{1 b}-\mathbf{1 f}$ were synthesized (Fig. 3). AH-1 had potent binding affinity for hVDR $\left[67 \%\right.$ of $\left.1 \alpha, 25(\mathrm{OH})_{2} \mathrm{D}_{3}\right]$ and increased transactivation activity in human osteosarcoma (HOS) cells $\left(\mathrm{EC}_{50} 10\right.$ $\mathrm{pM})$ compared to that of $1 \alpha, 25(\mathrm{OH})_{2} \mathrm{D}_{3}$ $\left(\mathrm{EC}_{50} 26 \mathrm{pM}\right) . \mathrm{AH}-1$ was evaluated for its in vivo therapeutic effect using ovariectomized (OVX) rats as an osteoporosis model animal. AH-1 increased the bone mineral density (BMD) of spine (L4-L5) bone mass at low doses of 0.007 and $0.02 \mu \mathrm{g} / \mathrm{kg} /$ day 5 times a week for 4 weeks, without significant side effects of increased serum calcium, such as hypercalcemia, compared to that of $1 \alpha, 25(\mathrm{OH})_{2} \mathrm{D}_{3}{ }^{.}{ }^{.10]}$

For AH-1 synthesis, the A-ring precursors of enynes, 2-substituted tetrazole $\mathbf{4 a}$ and 1-substituted isomer $\mathbf{4 b}$, were synthesized from methyl 3-deoxy-3-C-ethenyl-

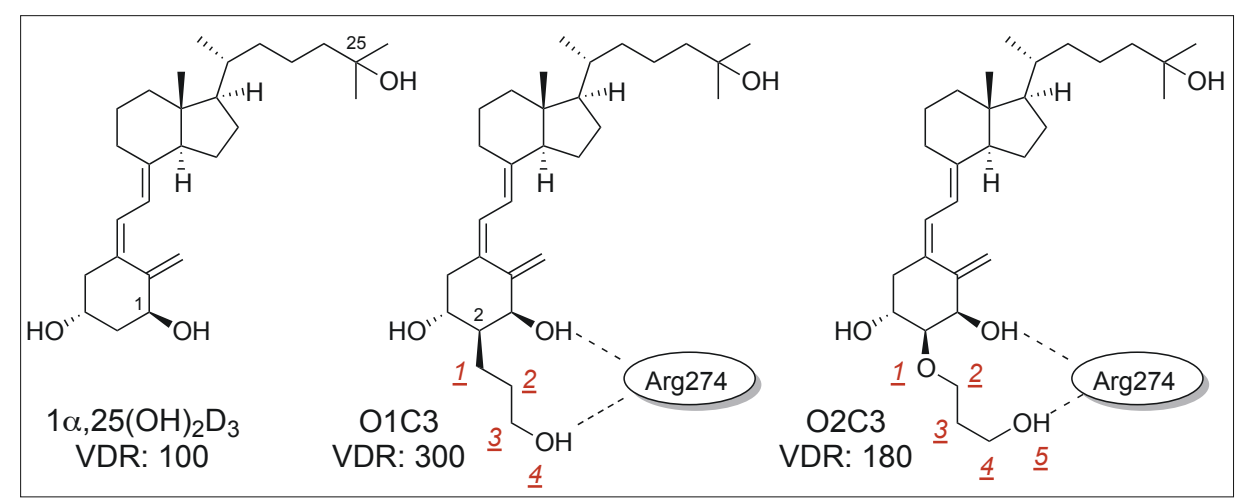

Fig. 1. Structures of $1 \alpha, 25(\mathrm{OH})_{2} \mathrm{D}_{3}$ and synthetic vitamin $\mathrm{D}$ analogs $\mathrm{O} 1 \mathrm{C} 3$ and $\mathrm{O} 2 \mathrm{C} 3$ with $2 \alpha$-functionalization, which have potent VDR binding affinity and biological activity as superagonists.

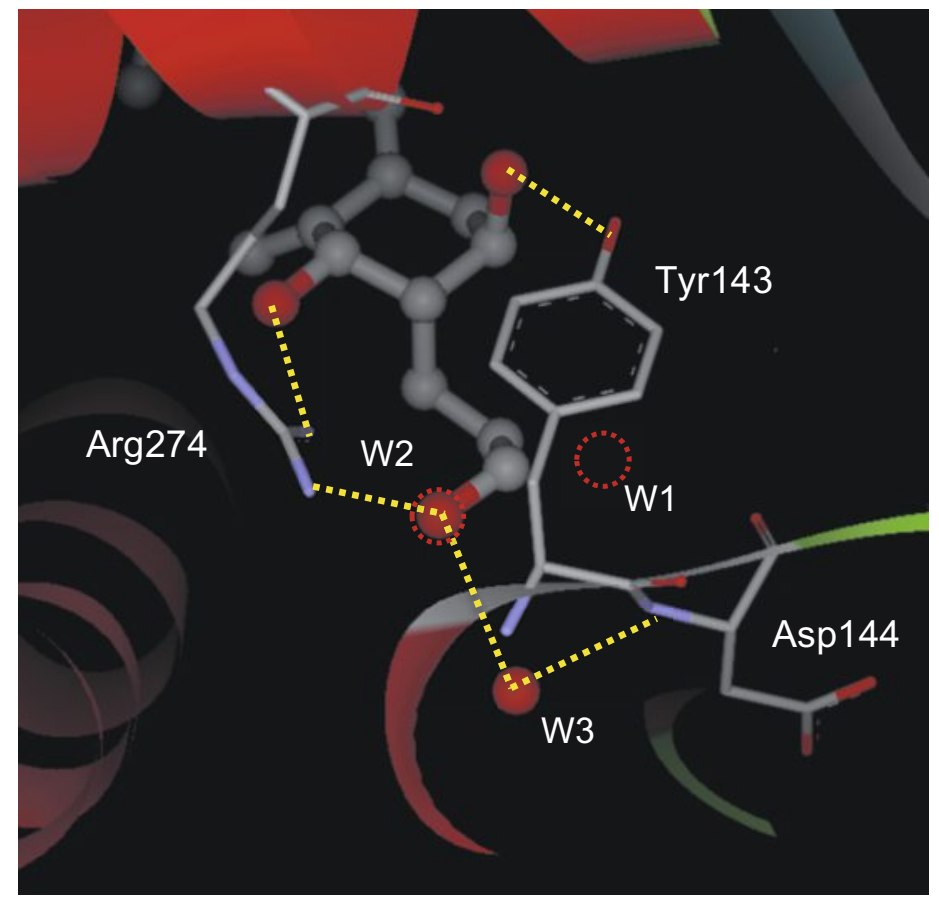

Fig. 2. X-ray studies on hVDR LBD-O1C3 complex. The A-ring part is magnified, and $\mathrm{W} 1-3$ are water molecules in the original hVDR LBD(active vitamin $\mathrm{D}_{3}$ ) complex. ${ }^{[3]}$ The Protein Data Bank accession number for the coordinates of the structure of the VDR complex with $01 \mathrm{C} 3$ is 2HB7. ${ }^{[4]}$

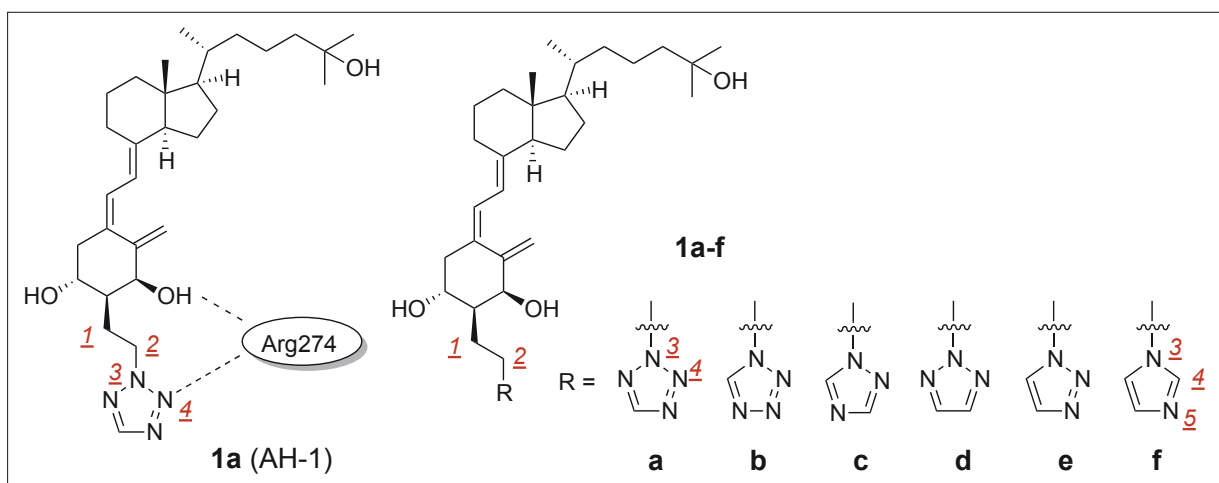

Fig. 3. Structures of $\mathrm{AH}-1$ with an azole ring and related synthesized analogs. Figure reproduced with permission of the American Chemical Society from ref. [10a].

altropyranoside $2,{ }^{[11]}$ which was available from methyl $\alpha$-D-glucoside (Scheme 1). Compound 2 was converted to enyne alcohol 3, and a Mitsunobu reaction between 3 and $1 H$-tetrazole gave the desired protected enynes $\mathbf{4 a}$ and $\mathbf{4 b}$ in yields of $81 \%$ and $19 \%$, respectively. Each synthetic step proceeded smoothly, giving good to high yields. The chemical structures of these two isomeric enynes were determined by comparing the ${ }^{1} \mathrm{H}$ NMR and ${ }^{13} \mathrm{C}$ NMR chemical shifts of the correlated methylene and methine $\mathrm{H}$ atoms of $\mathbf{4 a}$ and $\mathbf{4 b}$ (Scheme 1). [10a]

The A-ring precursor $\mathbf{4 a}$ and the CDring bromoolefin 5 were connected under Trost coupling conditions. The coupling product was deprotected and purified with HPLC for biological evaluation (Scheme 2). 


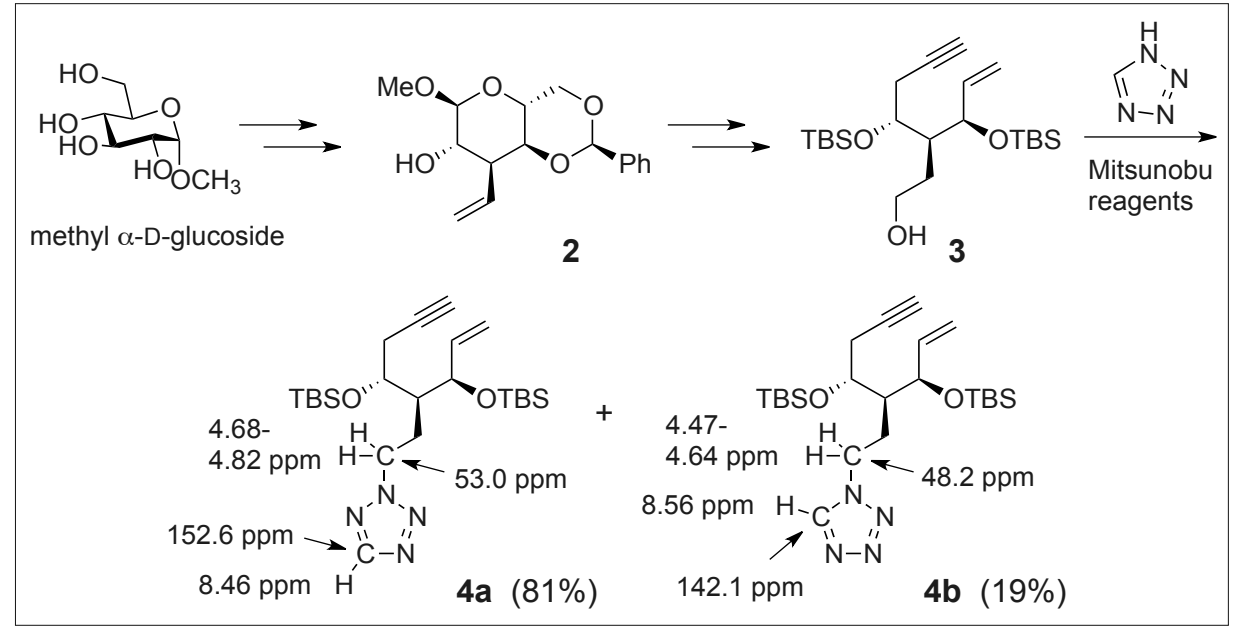

Scheme 1. Synthetic route to the A-ring precursor $\mathbf{4 a}$ of AH-1. Figure reproduced with permission of the American Chemical Society from ref. [10a].

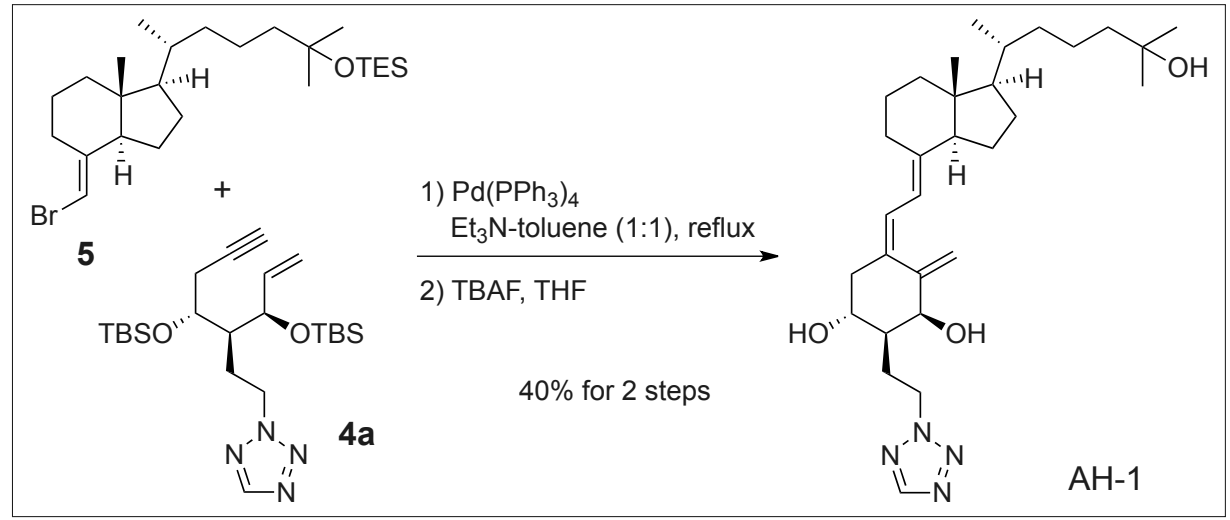

Scheme 2. Synthesis of $\mathrm{AH}-1$ by Trost coupling. Figure reproduced with permission of the American Chemical Society from ref. [10a].

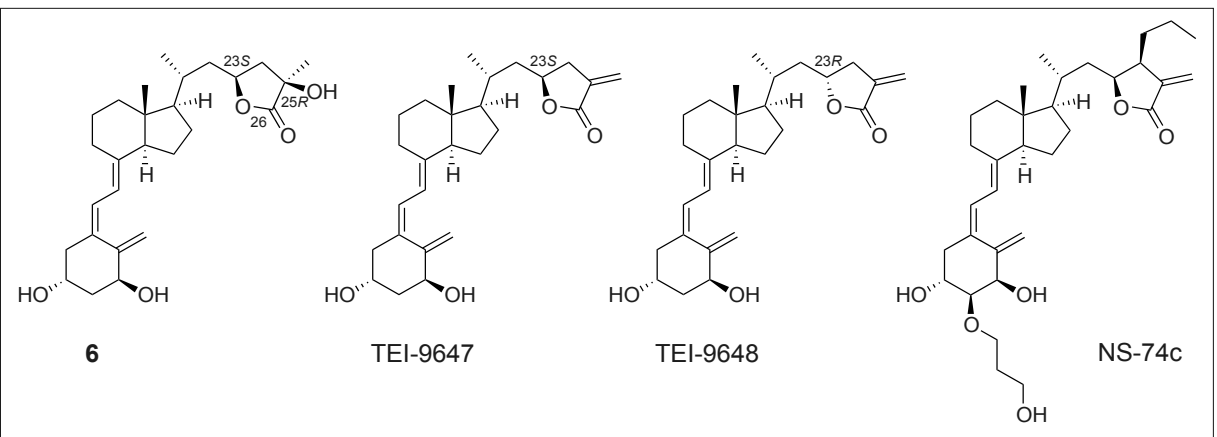

Fig. 4. The structures of the CYP24A1 lactone metabolite 6 from $1 \alpha, 25(\mathrm{OH})_{2} \mathrm{D}_{3}$ and its dehydrated analogs TEI-9647, TEI-9648, and NS-74c.

Initially, we thought that this potent bone-forming activity in vivo would be caused by the long half-life of AH-1, because AH-1 had a $2 \alpha$-substituent like $\mathrm{O} 1 \mathrm{C} 3$ and $\mathrm{O} 2 \mathrm{C} 3$, which were resistant to CYP24A1-deactivating metabolism. However, Prof. Sakaki of Toyama Prefectural University used a membrane fraction prepared from recombinant $E$. coli expressing human CYP24A1 in a kinetic analysis to show that the $\mathrm{k} / \mathrm{K}$ $\left(\mu \mathrm{M}^{-1} \mathrm{~min}^{-1}\right)$ value for $\mathrm{AH}-1$ was $31 \%$ of that for $1 \alpha, 25(\mathrm{OH})_{2} \mathrm{D}_{3},{ }^{[12]}$ which suggests that AH-1 is not as resistant to CYP24A1dependent metabolism as $\mathrm{O} 1 \mathrm{C} 3$ and
We examined the crystal structure of the truncated hVDR LBD-(AH-1) complex and confirmed pincer-type hydrogen bond formation of the $1 \alpha-\mathrm{OH}$ group, Arg274, and one of the nitrogen atoms of the tetrazole ring of $\mathrm{AH}-1 .[10,14]$

We also synthesized four 2-[3-(tetrazolyl)propyl]-19-nor-1 $\alpha, 25(\mathrm{OH})_{2} \mathrm{D}_{3}$ analogs, but these 19-nor analogs with a propyl group instead of the ethyl group as a linker had weak transactivation activity through hVDR in human osteosarcoma cells (HOS cells) $\left(\mathrm{EC}_{50} 7.3 \mathrm{nM}\right.$, when $1 \alpha, 25(\mathrm{OH})_{2} \mathrm{D}_{3}$ $0.23 \mathrm{nM})$. ${ }^{115]}$

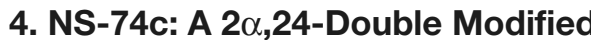 TEI-9647 Analog and Potent hVDR Antagonist}

Antagonists are receptor-binding molecules that inhibit the actions of their respective natural ligands, and many antagonists bind both the normal ligand binding site and neighboring sites. The first specific vitamin D receptor antagonists TEI-9647 and its (23R)-epimer TEI-9648, which are 25-dehydro-1 $\alpha$-hydroxyvitamin $\mathrm{D}_{3}-26,23$ lactones, bind the normal ligand binding site of the LBD of hVDR. TEI-9647 and TEI-9648 were discovered by the Teijin research group in 1999 by modifying the side chain of a $1 \alpha, 25$-dihydroxyvitamin $\mathrm{D}_{3}$-26,23-lactone metabolite $(\mathbf{6})^{[16]}$ derived from $1 \alpha, 25(\mathrm{OH})_{2} \mathrm{D}_{3}$ in the CYP24A1deactivating process (Fig. 4). [17]

TEI-9647 and TEI-9648 have an $\alpha$-methylene- $\gamma$-butyrolactone part on the side chain, which is a dehydrated form of the natural metabolite 6, and TEI-9647 in the $23 S$-configration is a stronger antagonist than TEI-9648 in the 23R-configuration. TEI-9647 inhibits the differentiation of HL-60 cells and suppresses the gene expression of CYP24A1 in HOS cells and in HL-60 cells induced by $1 \alpha, 25(\mathrm{OH})_{2} \mathrm{D}_{3}{ }^{[17]}$ VDR antagonists may be potent therapeutic agents for some diseases caused by hypersensitivity to $1 \alpha, 25(\mathrm{OH})_{2} \mathrm{D}_{3}$, such as Paget's disease, which is the most extreme example of disordered bone remodeling and the second most common bone disease after osteoporosis in Anglo-Saxons. [18] Studies on Paget's disease suggest a specific increase in osteoclast sensitivity to the differentiation activity of $1 \alpha, 25(\mathrm{OH})_{2} \mathrm{D}_{3}$ as the principal mechanism for abnormal bone formation. ${ }^{[19]}$ TEI-9647 inhibits osteoclast formation induced by $1 \alpha, 25(\mathrm{OH})_{2} \mathrm{D}_{3}$ in Pagetic bone marrow cells. ${ }^{[20]}$

We synthesized almost 150 analogs of TEI-9647 based on the $2 \alpha$-functionalization concept with an additional C24-modification to improve both VDR binding affinity and the halflife of TEI-9647, which contains a chemically reactive $\alpha, \beta$-unsaturated lactone ring 
that is unstable in blood. ${ }^{[21,22]}$ We investigated $\mathrm{C} 2 \alpha$ and $\mathrm{C} 24$-double modification of vitamin $\mathrm{D}_{3}$ lactone analogs of TEI-9647 and found a potent compound $(23 S, 24 S)$ 25 -dehydro-2 $\alpha$-(3-hydroxypropoxy)-24propyl-1 $\alpha$-hydroxyvitamin $\quad \mathrm{D}_{3}-26,23$ lactone (NS-74c). NS-74c had almost 1000-fold higher antagonistic activity $\left(\mathrm{IC}_{50}=7.4 \mathrm{pM}\right)$ than that of the original TEI-9647 $\left(\mathrm{IC}_{50}=6.3 \mathrm{nM}\right)$. $^{[23]}$ The antagonistic activities were assessed by the NBTreduction method in terms of inhibition of HL-60 cell differentiation induced by 10 $\mathrm{nM}$ of $1 \alpha, 25(\mathrm{OH})_{2} \mathrm{D}_{3}$. The synthetic route is shown in Scheme 3.

The exo-methylene lactone structure is indispensable for the antagonistic activity of TEI-9647.[24] The LBD of the hVDR contains two cysteine residues, Cys403 on helix 11 and Cys410 in the hinge region between helix 11 and helix 12, which are close to the $\mathrm{CD}$-ring side chain of $1 \alpha, 25(\mathrm{OH})_{2} \mathrm{D}_{3}$ in the hVDR-ligand complex in X-ray studies. ${ }^{[3]}$ These two cysteines are important for antagonist activity of TEI-9647 on VDR. ${ }^{[25]}$ The nucleophilic thiol groups of Cys403 and Cys410 may attack the $\alpha$-methylene- $\gamma$-lactone of TEI9647 and its analogs via 1,4-addition to give a corresponding cysteine adduct.[26] When the exo-methylene moiety is located at a more favorable position to react with Cys403 and/or Cys410 after binding, the TEI-9647 analog has stronger VDR antagonistic activity. The potent antagonistic activity of NS-74c may occur because it is situated in a preferable position relative to the exo-methylene group toward the cysteine residues after binding the LBD of VDR.

\section{MART-10: A 2 $\alpha$-Modified 19-Norvitamin $D_{3}$ for Cancer Therapy}

Epidemiological studies have found that low plasma $25(\mathrm{OH}) \mathrm{D}$ levels increase the risk of cancer. ${ }^{[27]}$ The potent cellular modulatory properties of $1 \alpha, 25(\mathrm{OH})_{2} \mathrm{D}_{3}$, including anti-proliferation, anti-invasion, anti-angiogenesis, anti-inflammation, proapoptosis, and pro-differentiation, suggest that $1 \alpha, 25(\mathrm{OH})_{2} \mathrm{D}_{3}$ can be used as a therapeutic agent for cancer. ${ }^{[1]}$ However, $1 \alpha, 25(\mathrm{OH})_{2} \mathrm{D}_{3}$ can cause hypercalcemia, and safer analogs of $1 \alpha, 25(\mathrm{OH})_{2} \mathrm{D}_{3}$ that have less calcemic activity but retain antiproliferative activity are more attractive therapeutic agents.

In 1990, Perlman et al. synthesized 19-nor- $1 \alpha, 25(\mathrm{OH})_{2} \mathrm{D}_{3}$ and found that it induced the differentiation of human leukemia HL-60 cells in vitro with potency comparable to that of $1 \alpha, 25(\mathrm{OH})_{2} \mathrm{D}_{3}$, but with little or no calcemic effect in animals. ${ }^{28]}$ However, the removal of the 10(19)-me- thylidene group from the natural hormone $1 \alpha, 25(\mathrm{OH})_{2} \mathrm{D}_{3}$ reduces the VDR binding affinity because of the loss of hydrophobic interaction with the LBD of VDR. The binding affinity of 19-nor- $1 \alpha, 25(\mathrm{OH})_{2} \mathrm{D}_{3}$ is only $30 \%$ and $17 \%$ of $1 \alpha, 25(\mathrm{OH})_{2} \mathrm{D}_{3}$ for porcine VDR ${ }^{[29]}$ and calf thymus VDR, ${ }^{[30 a]}$ respectively. We modified the 19-norvitamin D skeleton with a $2 \alpha-(\omega$-hydroxy)alkyl group to improve VDR binding affinity similar to that of $\mathrm{O} 1 \mathrm{C} 3$, and we expected the calcemic activity of $1 \alpha, 25(\mathrm{OH})_{2} \mathrm{D}_{3}$ may decrease due to removal of its 10(19)-exomethylene group.

As shown in Scheme 4, the key coupling reaction of an A-ring ketone and a CD-ring for the C5-C6 double bond was performed by Julia-Kocienski olefination, and 2 $\alpha$-(3-hydroxypropyl)-1 $\alpha, 25-$ dihydroxy-19-norvitamin $\mathrm{D}_{3}$ (MART-10) and its 2-epimer MART-11 were synthesized. [30,31]

MART-10 has marked anti-tumor activity, which is about 2-3 magnitudes more active than $1 \alpha, 25(\mathrm{OH})_{2} \mathrm{D}_{3}$ in the prostate, liver, pancreatic, breast, anaplastic thyroid, head and neck cancer cells, and cholangiocarcinoma cells in culture. ${ }^{[31-34]}$ In a xenograft animal model inoculated with pancreatic cancer cells, MART-10 had 10-fold higher anti-tumor activity than that of $1 \alpha, 25(\mathrm{OH})_{2} \mathrm{D}_{3}$ without raising serum calcium. ${ }^{[33]}$ The higher biological activity of MART-10 occurs because of tighter binding to VDR, which is similar to that of $1 \alpha, 25(\mathrm{OH})_{2} \mathrm{D}_{3}$, from the 2 $\alpha$-(3-hydroxypropyl) group, [30a] and because of increased resistance to CYP24A1 degradation inside cells. CYP24A1 is only $1 \%$ effective on MART-10 compared to $1 \alpha, 25(\mathrm{OH})_{2} \mathrm{D}_{3}$, which results in a longer MART-10 halflife in cells. ${ }^{[9 a]}$ Another unique property of MART-10 is that it has a lower binding affinity for vitamin $\mathrm{D}$ binding protein (DBP) than $1 \alpha, 25(\mathrm{OH})_{2} \mathrm{D}_{3} \cdot{ }^{[34]}$ This lower binding affinity results in a higher concentration of bioavailable MART-10 in circulation for translocation to various target tissues, indicating the potential role of DBP in the effectiveness and pharmacodynamics of vitamin D analogs in vivo. We found that MART-10 was either non-calcemic or less calcemic than $1 \alpha, 25(\mathrm{OH})_{2} \mathrm{D}$ in vivo. ${ }^{[32 \mathrm{~b}, 33]}$ MART-11 with a $2 \beta$-(3-hydoxypropyl) group is also biologically active but less potent than MART-10. [30a,32a]

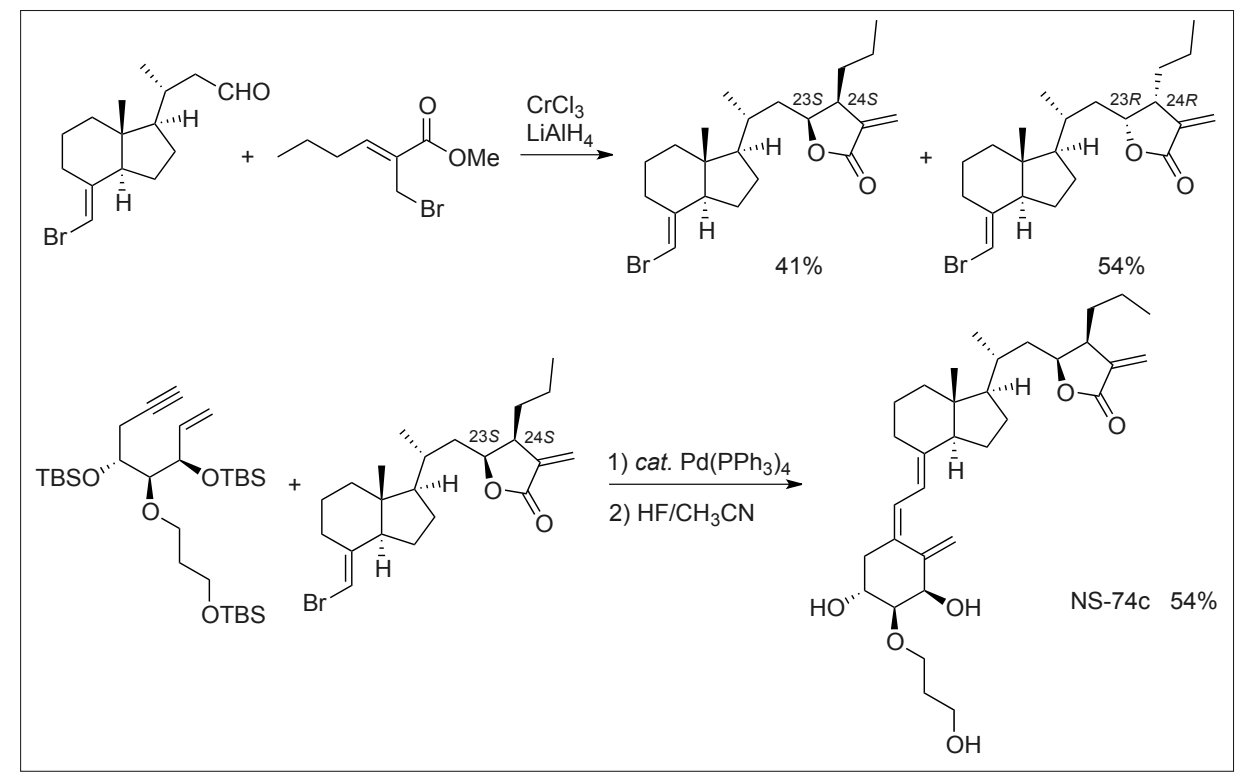

Scheme 3. Synthesis of a potent VDR-antagonist NS-74c. Figure reproduced with permission of the American Chemical Society from ref. [23].

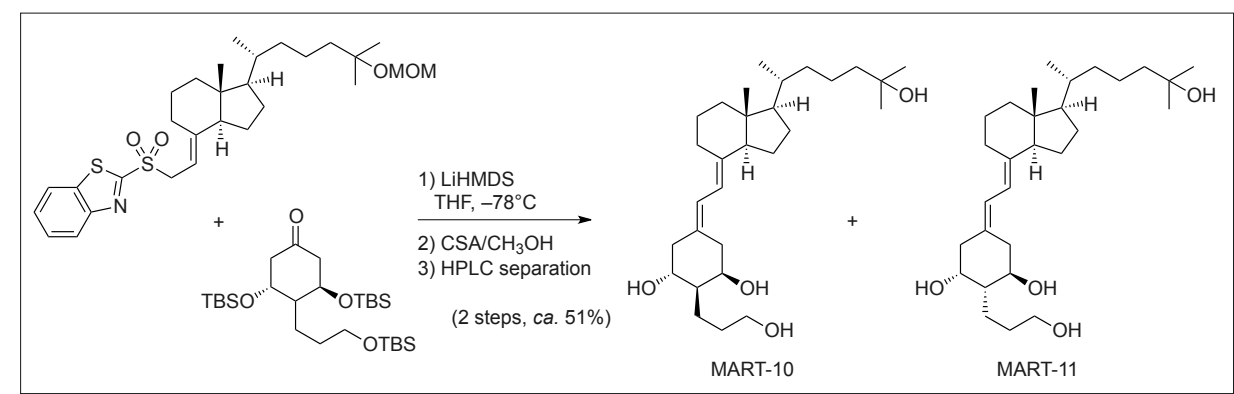

Scheme 4. Coupling reaction between the CD-ring sulfone and A-ring ketone via Julia-Kocienski olefination followed by deprotection. HPLC separation of C2-epimers resulted in MART-10 and MART11 (almost 1:1). Figure reproduced with permission of the American Chemical Society from ref. [30a]. 


\section{Stable 14-epi-19-Nortachysterols with High Binding Affinity for hVDR}

Exposure of the skin to sunlight is needed for the biosynthesis of vitamin $\mathrm{D}_{3}$. For photolysis of 7-dehydrocholesterol (provitamin $\mathrm{D}_{3}$ ) in the skin, previtamin $\mathrm{D}_{3}$ is initially produced through a photochemical electrocyclic reaction. Previtamin $\mathrm{D}_{3}$ is thermodynamically unstable and rapidly isomerized to a vitamin $\mathrm{D}_{3}$ skeleton at body temperatures via a [1,7]-sigmatropic rearrangement. Photosynthesized vitamin $D_{3}$ enters the blood circulation where it forms a complex with DBP. The remaining cutaneous previtamin $\mathrm{D}_{3}$ with a conjugate triene system continues to be irradiated by sunlight in thermal isomerization equilibrium with vitamin $D_{3}$, which results in lumisterol and tachysterol, and the remaining vitamin $\mathrm{D}_{3}$ in the skin may be converted to 5,6-transvitamin $\mathrm{D}_{3}$, suprasterol I, and suprasterol II by continuous sunlight irradiation (Scheme 5) ${ }^{[35]}$ We synthesized structural modifications of tachysterol for cell-regulating and bone-remodeling activity without unfavorable side effects, such as hypercalcemia and hypercalciuria, for chemotherapy. However, the tachysterol structure was unstable under normal conditions, and we found that 14-epi-tachysterol was stable enough to modify the $2 \alpha$-position.

Previtamin $\mathrm{D}_{3}$ is a precursor of vitamin $\mathrm{D}_{3}$, and photo-activated previtamin $\mathrm{D}_{3}$ generates tachysterol and lumisterol. Irradiation with UV-C $(254 \mathrm{~nm})$ results in a higher yield of tachysterol. ${ }^{[36]}$ Although vitamin $\mathrm{D}_{3}$ is stable in air at ambient temperature, isotachysterol, the acid-catalyzed isomer of both vitamin $\mathrm{D}_{3}$ and tachysterol, is labile in air and is converted into autoxidation products via a free radical chain mechanism even in the dark at ambient temperature. ${ }^{[36 c, d]}$

First, 14-epi-19-norprevitamin D analogs were synthesized and compared to 14-epi-previtamin $\mathrm{D}_{3}$ analogs. ${ }^{[37,38]} \mathrm{We}$ found proton-catalyzed isomerization of synthesized 14-epi-19-norprevitamin $\mathrm{D}_{3}$ skeletons to the stable 14-epi-19-nortachysterols.[39] We synthesized 14-epi$1 \alpha, 25$-dihydroxy-19-nortachysterol and its 2-substituted analogs using a Stille coupling reaction between the A-ring precursor vinylstannane and the CD-ring triflate (Scheme 6). Some A-ring precursors in Scheme 6 were known compounds, and the details are described previously. ${ }^{[37,39-41]}$

The A-ring precursor enynes were converted to the corresponding vinylstannanes. Stille coupling was used to connect each vinylstannane and CD-ring triflate, and the coupled compounds were deprotected. The target molecules of 14-epi-1 $\alpha, 25$ dihydroxy-19-nortachysterol, its 2-exo-

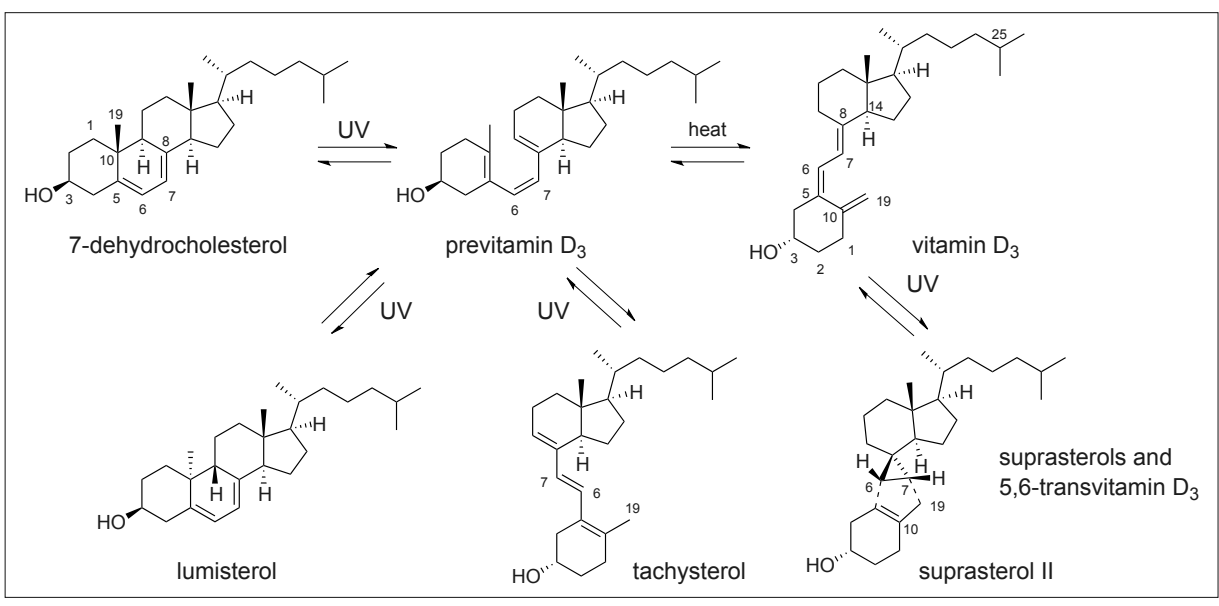

Scheme 5. Photolysis step of 7-dehydrocholesterol with sunlight for vitamin $D_{3}$ biosynthesis in the skin. methylene-, 2-(3-hydroxypropyl)-, and 2-(3-hydroxypropoxy)-substituted analogs were obtained. The 2-(3-hydroxypropyl)substituted analog was separated by HPLC for the $2 \alpha$ - and $2 \beta$-diastereomers. ${ }^{[40]}$ For further modification on the A-ring part, regioselective hydrogenation of the 2-exomethylene analog at the terminal alkene was successfully accomplished with Wilkinson's catalyst to give 2-methyl substituted diastereomers, which were separated by HPLC. ${ }^{[39]}$

The new compounds based on the 14-epi-19-nortachysterol skeleton were more stable than tachysterol, which is easily converted to vitamin $\mathrm{D}_{3}$ by UV irradiation ${ }^{[36 b]}$ or isomerized to isotachysterol and further oxidized by $\mathrm{O}_{2}$ under acidic conditions resulting in a complex mixture. ${ }^{[36 c, d]}$ The 14-epi-19-nortachysterols shown in Fig. 5, except the natural trans-CD-ring version, were the first examples of stable tachysterol analogs.

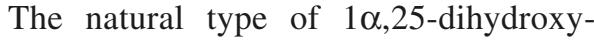
19-nortachysterol was also synthesized, but a coupling product was isolated after the Stille coupling reaction using trans-CD-ring triflate, and the product 1 $\alpha, 25$-dihydroxy-19-nortachysterol was unstable and gradually decomposed even under neutral conditions at room temperature so we were unable to evaluate its biological activity. Because the 14-epiCD-ring system of $c i s$-hydrindane prefers the $\mathrm{C} 8$,9-endo double bond rather than the C7,8-exo double bond, ${ }^{[42]}$ 14-epimerization is essential to stabilize the tachysterol skeleton.

VDR binding affinity of the synthesized seven 14-epi-1 $\alpha, 25$-dihydroxy-19nortachysterol analogs was tested. The 2-exomethylene analog had the highest binding affinity for hVDR, ca. $83 \%$ affinity compared to the natural hormone

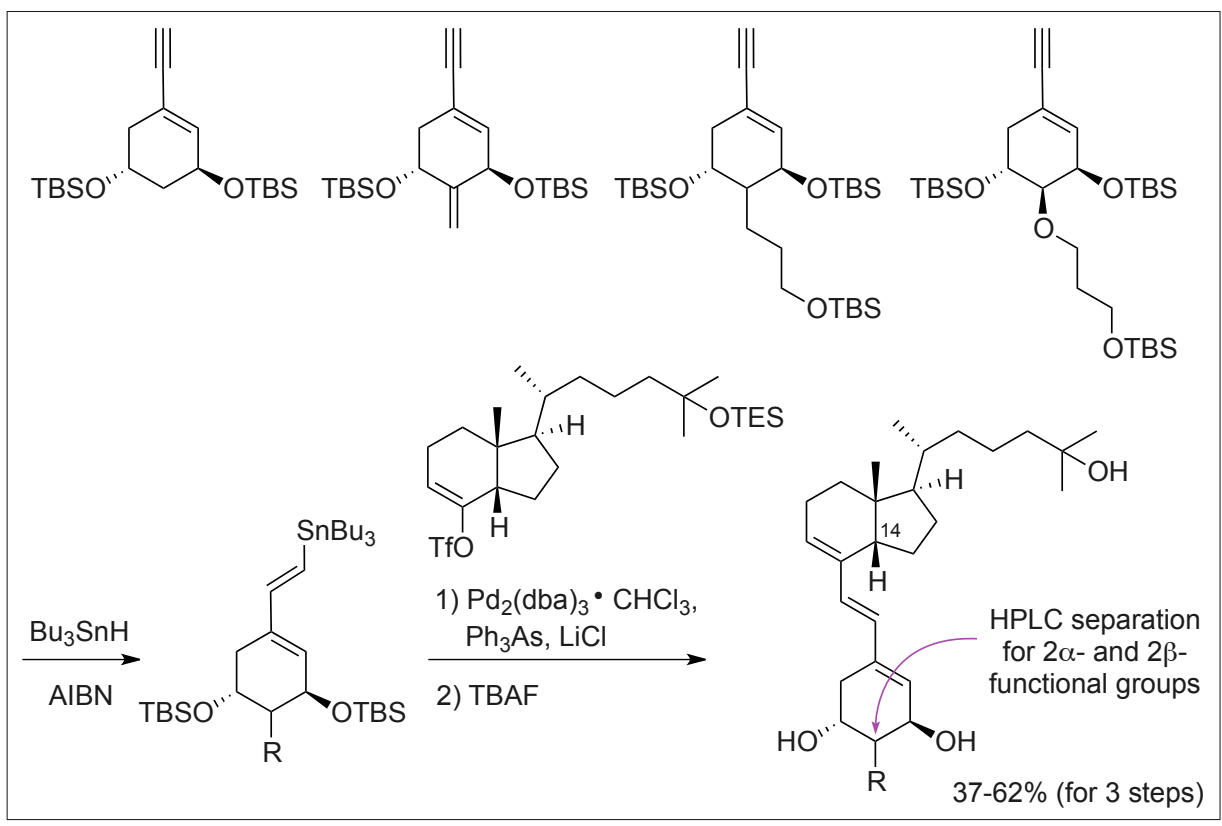

Scheme 6. Stille coupling reaction to construct 2-substituted 14-epi-1 $\alpha, 25$-dihydroxy-19nortachysterols. After the final deprotection, HPLC separation for $2 \alpha-$ and $2 \beta$-isomers was performed, if necessary. Figure reproduced with permission of Publisher. ${ }^{[39-41]}$ 


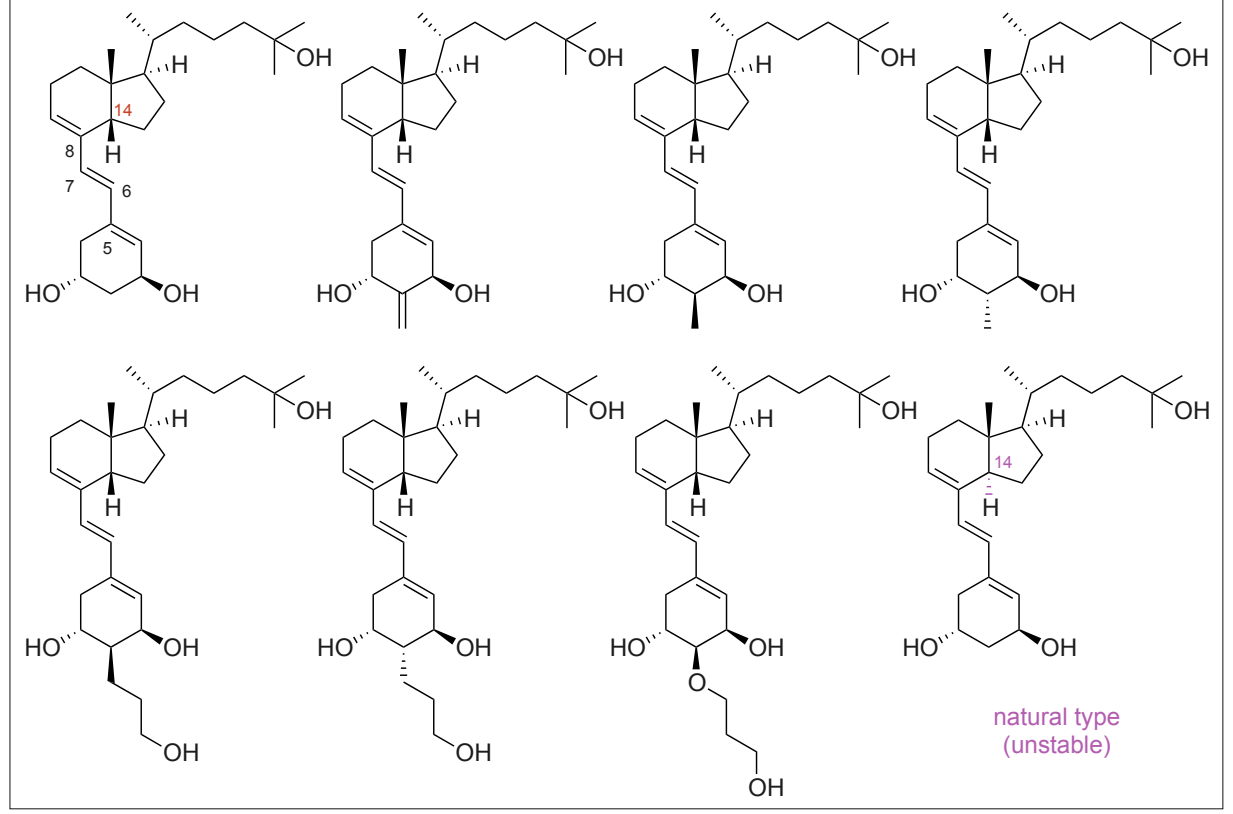

Fig. 5. Synthesized 1 1,25-dihydroxy-19-nortachysterol analogs using the Stille coupling reaction.

$1 \alpha, 25(\mathrm{OH})_{2} \mathrm{D}_{3}(100 \%)$, and the $2 \alpha$-methyl analog had almost the same level of binding affinity (71\%) as the exomethyl analog. The $2 \alpha$-methyl analog was a stronger binder of hVDR than the $2 \beta$-counterpart $(48 \%)$ and had the same tendency as 2-methyl$1 \alpha, 25(\mathrm{OH})_{2} \mathrm{D}_{3} \cdot{ }^{[43 \mathrm{a}, \mathrm{b}]}$ There was a positive effect of 2-exomethylene and 2-methyl groups on VDR binding affinity compared to that of 2-non-substituted 14-epi-19-nortachysterol $(15 \%)$, similar to that of vita$\min \mathrm{D}_{3}$ and 19-norvitamin $\mathrm{D}_{3}{ }^{[43]}$

However, $\quad 2 \alpha$-(3-hydroxypropyl)-,

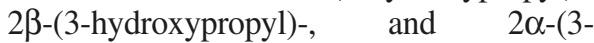
hydroxypropoxy)-substituted $14-e p i-1 \alpha, 25$ dihydroxy-19-nortachysterol had unexpected binding affinity compared to that of 2-nonsubstituted 14-epi-19-nortachysterol $(5.6 \%$, $48 \%$, and $3.2 \%$ compared to $15 \%$, respectively). For 14-epi-19-nortachysterol, the $2 \alpha$-long substituent was a bulky group for binding to hVDR, and the $2 \beta$-(3-hydroxypropyl) A-ring had much higher binding affinity $(48 \%)$ than its $2 \alpha$-counterpart $(5.6 \%)$ and the non-substituted compound (15\%). We identified their binding configurations and interactions with amino acid residues in the LBD of hVDR by $\mathrm{X}$-ray co-crystallographic analysis. ${ }^{[40]} \mathrm{In}$ the LBD of hVDR, the terminal hydroxy group of the $2 \alpha$-substituent of O1C3 forms hydrogen bond networks both with Arg274 and one of the water molecules in the LBD, and consequently, has higher binding affinity confirmed by X-ray co-crystallographic analysis data. ${ }^{[4]}$ We analyzed the X-ray data of hVDR[2$\alpha$ - and 2 $\beta$-14-epi-(3-hydroxypropyl)-19nortachysterol] complexes, ${ }^{[40]}$ and found that these ligands bound to hVDR with C5,6-strans and C7,8-s-trans triene configuration, respectively, which was an unprecedented binding mode for seco-steroid analogs. ${ }^{[39]} \mathrm{In}$ this binding mode, the $2 \alpha$-substituted long chain was not appropriate for constructing hydrogen bond networks with Arg274, and this long substituent became a steric hindrance in the LBD of hVDR.

\section{Conclusions}

We found positive effects of $2 \alpha-(\omega-$ hydroxyalkylation) toward $1 \alpha, 25(\mathrm{OH})_{2} \mathrm{D}_{3}$ on VDR binding affinity and preliminary biological activities in vitro and in vivo, and synthesized unique molecules such as $\mathrm{O} 1 \mathrm{C} 3, \mathrm{O} 2 \mathrm{C} 3$, AH-1, NS-74c (TEI9647 analog), and MART-10. We also studied stable 14-epi-19-nortachysterol derivatives. According to X-ray co-crystallographic analyses of hVDR-(synthetic ligand) complexes, only 2-substituted 14-epi-19-nortachysterol analogs had different VDR binding.

We are investigating other types of vitamin D biological activities that do not depend on the VDR-signaling pathway. We aim to separate less well-known vitamin D function from canonical vitamin $\mathrm{D}$ activity, which depends on VDR binding.

\section{Acknowledgements}

The author thanks many of my excellent collaborators including those in the references. This study was supported in part by Grants-inAid from the Japan Society for the Promotion of Science (No. 15K07869 and 18K06556). The author is grateful to AMED-CREST, AMED (JP18gm0710007h0105) for partial support in the preparation of this manuscript.

\section{Received: July 17, 2018}

[1] For excellent books of vitamin D, see: a) D. Feldman, J. W. Pike, F. H. Glorieux, 'Vitamin D', 2 ${ }^{\text {nd }}$ Edn., Elsevier Academic Press, New York, 2005; b) D. Feldman, J. W. Pike, J. S. Adams, 'Vitamin D', 3rd Edn., Elsevier Academic Press: New York, 2011.
[2] a) R. M. Evans, Science 1988, 240, 889; b) D. J. Mangelsdorf, C. Thummel, M. Beato, P. Herrlich, G. Schütz, K. Umesono, B. Blumberg, P. Kastner, M. Mark, P. Chambon, R. M. Evans, Cell 1995, 83, 835; c) P. Chambon, Mol. Endocrinol. 2005, 19, 1418

[3] N. Rochel, J. M. Wurtz, A. Mitschler, B Klaholz, D. Moras, Mol. Cell 2000, 5, 173.

[4] S. Hourai, T. Fujishima, A. Kittaka, Y. Suhara, H. Takayama, N. Rochel, D. Moras, J. Med. Chem. 2006, 49, 5199. The Protein Data Bank accession numbers for the coordinates of the structures of the VDR complex with O1C3 and $\mathrm{O} 2 \mathrm{C} 3$ are $2 \mathrm{HB} 7$ and $2 \mathrm{HAR}$, respectively.

[5] a) Y. Suhara, K. Nihei, M. Kurihara, A. Kittaka, K. Yamaguchi, T. Fujishima, K. Konno, N. Miyata, H. Takayama, J. Org. Chem. 2001, 66, 8760; b) Y. Suhara, K. Nihei, H. Tanigawa, T. Fujishima, K. Konno, K. Nakagawa, T. Okano, H. Takayama, Bioorg. Med. Chem. Lett. 2000, 10, 1129 .

[6] a) A. Kittaka, Y. Suhara, H. Takayanagi, T. Fujishima, M. Kurihara, H. Takayama, Org. Lett. 2000, 2, 2619; b) N. Saito, Y. Suhara, M. Kurihara, T. Fujishima, S. Honzawa, H. Takayanagi, T. Kozono, M. Matsumoto, M. Ohmori, N. Miyata, H. Takayama, A. Kittaka, J. Org. Chem. 2004, 69, 7463.

[7] For our review, see: N. Saito, S. Honzawa, A Kittaka, Curr. Top. Med. Chem. 2006, 6, 1273.

[8] E. Takahashi, K. Nakagawa, Y. Suhara, A. Kittaka, K. Nihei, K. Konno, H. Takayama, K. Ozono, T. Okano, Biol. Pharm. Bull. 2006, 29 , 2246.

[9] a) K. Yasuda, S. Ikushiro, M. Kamakura, M. Takano, N. Saito, A. Kittaka, T. C. Chen, M. Ohta, T. Sakaki, J. Steroid Biochem. Mol. Biol. 2013, 133, 84; b) D. Abe, T. Sakaki, T. Kusudo, A. Kittaka, N. Saito, Y. Suhara, T. Fujishima, H. Takayama, H. Hamamoto, M. Kamakura, M. Ohta, K. Inouye, Drug Metab. Dispos. 2005, 33, 778 .

[10] a) M. Matsuo, A. Hasegawa, M. Takano, H. Saito, S. Kakuda, T. Chida, K. Takagi, E. Ochiai, K. Horie, Y. Harada, M. TakimotoKamimura, K. Takenouchi, D. Sawada, A. Kittaka, ACS Med. Chem. Lett. 2013, 4, 671; b) M. Matsuo, A. Hasegawa, M. Takano, H. Saito, S. Kakuda, K. Takagi, E. Ochiai, K. Horie, M. Takimoto-Kamimura, K. Takenouchi, D. Sawada, A. Kittaka, J. Steroid Biochem. Mol. Biol. 2014, 144, 201. The Protein Data Bank accession numbers for the coordinates of the structures of the VDR complex with $\mathrm{AH}-1$ and compound $1 \mathrm{~b}$ are 4ITE and 4ITF, respectively.

[11] S. Honzawa, Y. Yamamoto, K. Hirasaka, H. Takayama, A. Kittaka, Heterocycles 2003, 61, 327.

[12] K. Yasuda, E. Tohyama, M. Takano, A. Kittaka, M. Ohta, S. Ikushiro, T. Sakaki, J. Steroid Biochem. Mol. Biol. 2018, 178, 333.

[13] M. Takano, K. Yasuda, E. Tohyama, E. Higuchi, T. Sakaki, A. Kittaka, J. Steroid Biochem. Mol. Biol. 2017, 173, 75.

[14] A. Kittaka, M. Takano, H. Saitoh, in 'Vitamins and Hormones Vol. 100', Ed. G. Litwack, Elsevier Inc. Academic Press, Burlington, 2016, pp. 379-394.

[15] M. Takano, E. Higuchi, K. Higashi, K. Hirano, A. Takeuchi, D. Sawada, A. Kittaka, Heterocycles 2015, 90, 1274.

[16] S. Ishizuka, S. Ishimoto, A. W. Norman, Biochemistry 1984, 23, 1473.

[17] a) D. Miura, K. Manabe, K. Ozono, M. Saito, Q. Gao, A. W. Norman, S. Ishizuka, J. Biol. Chem. 1999, 274, 16392; b) K. Ozono, M. Saito, D. Miura, T. Michigami, S. Nakajima, S. Ishizuka, J. Biol. Chem. 1999, 274, 32376; c) S. Ishizuka, D. Miura, H. Eguchi, K. Ozono, M. Chokki, T. Kamimura, A. W. Norman, Arch. Biochem. Biophys. 2000, 380, 92. 
[18] Reviews on Paget's disease, see: S. V. Reddy, $J$. Cell Biochem. 2004, 93, 688

[19] S. Ishizuka, N. Kurihara, S. V. Reddy, J. Cornish, T. Cundy, G. D. Roodman, Endocrin. 2005, 146, 2023

[20] S. Ishizuka, N. Kurihara, D. Miura, K. Takenouchi, J. Cornish, T. Cundy, S. V. Reddy, G. D. Roodman, J. Steroid Biochem. Mol. Biol. 2004, 89-90, 331.

[21] For our review, see: N. Saito, A. Kittaka, ChemBioChem. 2006, 7, 1478.

[22] a) N. Saito, H. Saito, M. Anzai, A. Yoshida, T. Fujishima, K. Takenouchi, D. Miura, S. Ishizuka, H. Takayama, A. Kittaka, Org. Lett. 2003, 5, 4859; b) N. Saito, T. Matsunaga, T. Fujishima, M. Anzai, H. Saito, K. Takenouchi, D. Miura, S. Ishizuka, H. Takayama, A. Kittaka Org. Biomol. Chem. 2003, 1, 4396; c) N. Saito, M. Masuda, T. Matsunaga, H. Saito, M. Anzai, K. Takenouchi, D. Miura, S. Ishizuka, M Takimoto-Kamimura, A. Kittaka, Tetrahedron 2004, 60, 7951; d) N. Saito, M. Masuda, H. Saito, K. Takenouchi, S. Ishizuka, J. Namekawa, M. Takimoto-Kamimura, A. Kittaka, Synthesis 2005, 2533.

[23] N. Saito, T. Matsunaga, H. Saito, M. Anzai, K. Takenouchi, D. Miura, J. Namekawa, S. Ishizuka, A. Kittaka, J. Med. Chem. 2006, 49, 7063.

[24] K. Takenouchi, R. Sogawa, K. Manabe, H. Saitoh, Q. Gao, D. Miura, S. Ishizuka, J. Steroid Biochem. Mol. Biol. 2004, 89-90, 31.

[25] a) E. Ochiai, D. Miura, H. Eguchi, K. Takenouchi, Y. Harada, Y. Azuma, T. Kamimura, S. Ishizuka, J. Bone Miner. Res. 2003, 18 (sup pl. 2), S103; b) E. Ochiai, D. Miura, H. Eguchi, S. Ohara, K. Takenouchi, Y. Harada, Y. Azuma, T. Kamimura, A. W. Norman, S. Ishizuka, Mol. Endocrinol. 2005, 19, 1147; c) M. Peräkylä, F. Molnár, C. Carlberg, Chem. Biol. 2004, 11 , 1147

[26] Some biologically active natural products having an $\alpha$-methylene- $\gamma$-lactone structure react with the thiol group of cysteine to give the corresponding cysteine adduct: S. M. Kupchan, D. C. Fessler, M. A. Eakin, T. J. Giacobbe, Science 1970, 168, 376.

[27] I. M. Shui, L. A. Mucci, P. Kraft, R. M Tamimi, S. Lindstrom, K. L. Penney, K. Nimptsch, B. W. Hollis, N. DuPre, E. A Platz, M. J. Stampfer, E. Giovannucci, J. Natl. Cancer Inst. 2012, 104, 1.

[28] K. L. Perlman, R. R. Sicinski, H. K. Schnoes, H. F. DeLuca, Tetrahedron Lett. 1990, 31, 1823.

[29] X. Zhou, G.-D. Zhu, D. Van Haver, M. Vandewalle, P. J. De Clercq, A. Verstuyf, R. Bouillon, J. Med. Chem. 1999, 42, 3539 .

[30] a) K. Ono, A. Yoshida, N. Saito, T. Fujishima, S. Honzawa, Y. Suhara, S. Kishimoto, T. Sugiura, K. Waku, H. Takayama, A. Kittaka, J. Org. Chem. 2003, 83, 7407; b) A. Yoshida, K. Ono, Y. Suhara, N. Saito, H. Takayama, A. Kittaka, Synlett 2003, 1175.
[31] For our review articles, see: a) A. Kittaka, A. Yoshida, K.-C. Chiang, M. Takano, D. Sawada, T. Sakaki, T. C. Chen, Future Med. Chem. 2012, 4, 2049; b) T. C. Chen, A. Kittaka, ISRN Urology 2011, Article ID 301490.

[32] a) T. C. Chen, K. S. Persons, S. Zheng, J. Mathieu, M. F. Holick, Y. F. Lee, B. Bao, M. A. Arai, A. Kittaka, J. Steroid Biochem. Mol. Biol. 2007, 103, 717; b) D. Iglesias-Gato, S. Zheng, J. N. Flanagan, L. Jiang, A. Kittaka, T. Sakaki, K. Yamamoto, T. Itoh, N. K. LeBrasseur, G. Norstedt, T. C. Chen, J. Steroid Biochem. Mol. Biol. 2011, 127, 269; c) K.-C. Chiang, C.-N. Yeh, H.-Y. Chen, J.-m. Lee, H.-H. Juang, M.F. Chen, M. Takano, A. Kittaka, T. C. Chen, Steroids 2011, 76, 1513; d) K.-C. Chiang, C.-N. Yeh, S.-C. Chen, S.-C. Shen, J.-T. Hsu, T.-s. Yeh, J.-H. S. Pang, L.-J. Su, M. Takano, A. Kittaka, H.-H. Juang, T. C. Chen, Evidence-Based Complementary and Alternative Medicine 2012, Article ID 310872; e) K.-C. Chiang, C.N. Yeh, J.-T. Hsu, L.-W. Chen, S.-F. Kuo, C.-C. Sun, C.-C. Huang, J.-H. S. Pang, J. N. Flanagan, M. Takano, A. Kittaka, H.-H. Juang, S.-W. Yang, T. C. Chen, J. Steroid Biochem. Mol. Biol. 2013, 138, 427; f) K.-C. Chiang, S.-C. Chen, C.-N. Yeh, J.-H. S. Pang, S.-C. Shen, J.-T. Hsu, Y.-Y. Liu, L.-W. Chen, S.-F. Kuo, M. Takano, A. Kittaka, C.-C. Sun, H.-H. Juang, T. C. Chen, J. Steroid Biochem. Mol. Biol. 2014, 139, 54; g) K.-C. Chiang, C.-N. Yeh, J.-T. Hsu, Y.-Y. Jan, L.-W. Chen, S.-F. Kuo, M. Takano, A. Kittaka, T.-C Chen, W.-T. Chen, J.-H. S.Pang, T.-S. Yeh, H.-H. Juang, Cancer Lett. 2014, 354, 235; h) K.-C. Chiang, S.-F. Kuo, C.-H. Chen, S. Ng, S.F. Lin, C.-N. Yeh, L.-W. Chen, M. Takano, T. C. Chen, H.-H. Juang, A. Kittaka, J.-D. Lin, J.-H. S. Pang, Cancer Lett. 2015, 369, 76; i) K.-C. Chiang, C.-C. Sun, M.-H. Chen, C.-Y. Huang, J.-T. Hsu, T.-S. Yeh, L.-W. Chen, S.-F. Kuo, H. H. Juang, M. Takano, A. Kittaka, T. C. Chen, C. N. Yeh, J.-H. S. Pang, J. Steroid Biochem. Mol. Biol. 2016, 155, 26; j) K.-C. Chiang, T.S. Yeh, S.-C. Chen, J.-H. S. Pang, C.-N. Yeh, J.-T. Hsu, L.-W. Chen, S.-F. Kuo, M. Takano, A. Kittaka, T. C. Chen, C.-C. Sun, H.-H. Juang, Int. J. Mol. Sci. 2016, 17, 606; k) S.-W. Yang, C.-Y. Tsai, Y.-C. Pan, C.-N. Yeh, J.-H. S. Pang, M. Takano, A. Kittaka, H.-H. Juang, T. C. Chen, K.-C. Chiang, Drug Design, Development and Therapy, 2016, 10, 1995; 1) K.-C. Chiang, C.N. Yeh, J.-H. S. Pang, J.-T. Hsu, T.-S. Yeh, L.W. Chen, S.-F. Kuo, P.-J. Hsieh, Y.-C. Pan, M. Takano, T. C. Chen, T.-H. Feng, A. Kittaka, H.-H. Juang, Anticancer Res. 2016, 36, 3307; m) K.-C. Chiang, T.-S. Yeh, C.-C. Huang, Y.-C. Chang, H.-H. Juang, C.-T. Cheng, J.-H. S. Pang, J.-T. Hsu, M. Takano, T. C. Chen, A. Kittaka, M. Hsiao, C.-N. Yeh, Sci. Rep. 2017, 7, 43773; n) K.-C. Chiang, C.-N. Yeh, J.-H. S. Pang, J.T. Hsu, T.-S. Yeh, L.-W. Chen, S.-F. Kuo, M. Takano, T. C. Chen, A. Kittaka, P.-J. Hsieh, H.H. Juang, Anticancer Res. 2017, 37, 6215.
[33] K.-C. Chiang, C.-N. Yeh, J.-T. Hsu, T.-s. Yeh, Y.-y. Jan, C.-T. Wu, H.-Y. Chen, S.-C. Jwo, M. Takano, A. Kittaka, H.-H. Juang, T. C. Chen, Cell Cycle 2013, 12, 1316.

[34] J. N. Flanagan, S. Zheng, K. C. Chiang, A. Kittaka, T. Sakaki, S. Nakabayashi, X. Zhao, R. A. Spanjaard, K. S. Persons, J. S. Mathieu, M. F. Holick, T. C. Chen, Anticancer Res. 2009, 29 , 3547.

[35] M. F. Holick, 'Photobiology of Vitamin D' in 'Vitamin D', 3rd Edn., Eds. D. Feldman, J. W. Pike, J. S. Adams, Elsevier Academic Press, New York, 2011, pp. 13-22.

[36] a) M. A. Zmijewski, W. Li, J. K. Zjawiony, T. W. Sweatman, J. Chen, D. D. Miller, A. T. Slominski, Photochem. Photobiol. Sci. 2008, 7, 1570; b) P. J. Kocienski, B. Lythgoe, J. C. S. Perkin I 1980, 1400; c) X. Jin, X. Yang, L. Yang, Z.-L. Liu, F. Zhang, Tetrahedron 2004, 60,$2881 ;$ d) V. K. Agarwal, J. Steroid Biochem. 1990, 35, 149.

[37] Our review article, see: D. Sawada, A. Kittaka, Curr. Top. Med. Chem. 2014, 14, 2454 and references are therein.

[38] a) D. Sawada, T. Katayama, Y. Tsukuda, N. Saito, H. Saito, K. Takagi, E. Ochiai, S. Ishizuka, K. Takenouchi, A. Kittaka, Tetrahedron 2010, 66, 5407; b) D. Sawada, Y. Tsukuda, H. Saito, K Takagi, E. Ochiai, S. Ishizuka, K. Takenouchi, A. Kittaka, J. Steroid Biochem. Mol. Biol. 2010, 121, 20; c) D. Sawada, T. Katayama, Y. Tsukuda, N. Saito, M. Takano, H. Saito, K. Takagi, E. Ochiai, S. Ishizuka, K. Takenouchi, A. Kittaka, Bioorg. Med. Chem. Lett. 2009, 19, 5397.

[39] D. Sawada, Y. Tsukuda, H. Saito, S. Kakuda, M Takimoto-Kamimura, E. Ochiai, K. Takenouchi, A. Kittaka, J. Am. Chem. Soc. 2011, 133, 7215.

[40] D. Sawada, S. Kakuda, A. Takeuchi, F. Kawagoe, M. Takimoto-Kamimura, A. Kittaka, Org. Biomol. Chem. 2018, 16, 2448. The Protein Data Bank accession numbers for the coordinates of the structures of the VDR complex with $2 \alpha$ - and $2 \beta$-14-epi-(3-hydroxypropyl)-19-nortachysterol are 5 YT2 and 5YSY, respectively.

[41] D. Sawada, Y. Tsukuda, H. Saito, K. Takagi, S Kakuda, M. Takimoto-Kamimura, E. Ochiai, K. Takenouchi, A. Kittaka, J. Steroid Biochem. Mol. Biol. 2013, 136, 27.

[42] E. Havinga, Experientia 1973, 29, 1181.

[43] a) K. Konno, S. Maki, T. Fujishima, Z. Liu, D. Miura, M. Chokki, H. Takayama, Bioorg. Med. Chem. Lett. 1998, 8, 151; b) K. Konnno, T. Fujishima, S. Maki, Z. Liu, D. Miura, M. Chokki, M. Ishizuka, K. Yamaguchi, Y. Kan, M. Kurihara, N. Miyata, C. Smith, H. F. DeLuca, H. Takayama, J. Med. Chem. 2000, 43, 4247; c) For 2-exomethylene 19-norvitamin $\mathrm{D}_{3}$ analog, see: R. R. Sicinski, J. M. Prahl, C. M. Smith, H. F. DeLuca, J. Med. Chem. 1998, 41, 4662. 